\title{
Therapeutics in Duchenne Muscular Dystrophy
}

\author{
Jonathan B. Strober, MD \\ Director, Pediatric Muscular Dystrophy Association Clinic, Assistant Clinical Professor, Neurology \& Pediatrics, \\ University of California, San Francisco
}

\begin{abstract}
Summary: Duchenne muscular dystrophy (DMD) is a fatal disorder affecting approximately 1 in 3500 live born males, characterized by progressive muscle weakness. Several different strategies are being investigated in developing a cure for this disorder. Until a cure is found, therapeutic and supportive care is essential in preventing complications and improving the afflicted child's quality of life. Currently, corticosteroids are the only class of drug that has been extensively studied in this condition, with controversy existing over the use of these drugs, especially in light of the multiple side effects that may
\end{abstract}

occur. The use of nutritional supplements has expanded in recent years as researchers improve our abilities to use gene and stem cell therapies, which will hopefully lead to a cure soon. This article discusses the importance of therapeutic interventions in children with DMD, the current debate over the use of corticosteroids to treat this disease, the growing use of natural supplements as a new means of treating these boys and provides an update on the current state of gene and stem cell therapies. Key Words: Duchenne, muscular dystrophy, corticosteroids, gene therapy, stem cell therapy.

\section{INTRODUCTION}

Duchenne muscular dystrophy (DMD) is a fatal disorder affecting approximately 1 in 3500 live born males. It is characterized by progressive muscle weakness starting in the pelvic and shoulder girdle musculature then spreading to the extremities. Boys typically present at 3 -5 years of age and death often ensues during the third decade, most frequently from respiratory complications or cardiac failure. Although the exact pathophysiologic mechanism is unknown, the disease is due to the absence of dystrophin, a subsarcolemmal protein that adheres actin to the membrane bound dystroglycan complex (fig. 1). Many other integral proteins associated with the dystrophin complex have been identified, with mutations in the genes encoding these proteins leading to the large category of limb-girdle muscular dystrophies. The one unifying pathologic finding in these conditions is the evidence of chronic degeneration and regeneration seen on muscle biopsy, which includes the presence of endomysial fibrosis and fatty infiltration.

Even with a better understanding of the etiology of this condition that has developed over the two decades since dystrophin was discovered, we still do not have a

Correspondence: UCSF, Division of Child Neurology, 350 Parnassus Avenue, Suite 609, San Francisco, CA 94117, Ph: (415) 353-3651, Fax: (415) 353-2400, Email: stroberj@ neuropeds.ucsf.edu cure. While researchers are working on stem cell and gene therapies as potential cures, others are evaluating different medications and supplements that may have a positive impact on the quality of life for boys afflicted with this disorder and may even help prolong a child's lifespan.

One of the difficulties with studies evaluating different drugs is the difference between strength and function. It has been shown that a small reduction of muscle force can accompany a large reduction in functional ability. ${ }^{1}$ Conversely, although muscle force may become severely reduced, functional ability can remain stable for longer periods of time. ${ }^{2}$ Other researchers have reported a good correlation between strength and function in patients with spinal muscular atrophy. ${ }^{3}$ Studies have been further confounded due to the question of correlations between age and strength ${ }^{4}$ and age and function. ${ }^{1}$

\section{Therapeutic interventions}

Until a cure for DMD is discovered, the mainstay of treatment is supportive and preventative care with close monitoring of the child's cardiac and pulmonary status and for the development of scoliosis and contractures. In a study that followed 283 boys with DMD for up to 10 years, no correlation could be detected between the development of joint contractures and the use of passive joint stretching exercises. ${ }^{5}$ However, the prevention of contractures of the heel cords, knee extensors and ili- 


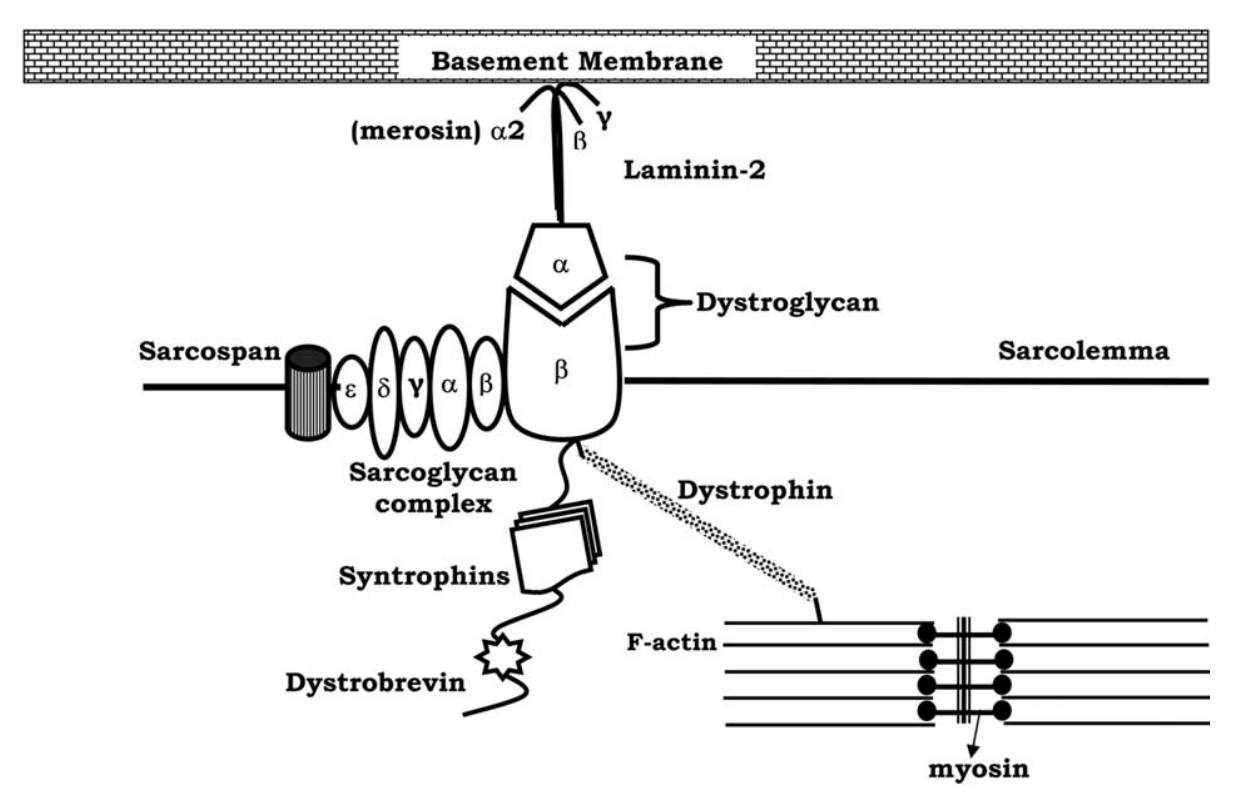

FIG. 1. Dystrophin and associated proteins.

otibial bands was statistically correlated to the use leg braces. Furthermore, heel cord contractures were reduced with regular use of night splints.

Exercise in ambulant DMD patients has been shown, in a few, randomized controlled studies, to have a beneficial effect, especially in those children with the least functional muscle impairment. ${ }^{6}$ This was especially true during the first few months of training, ${ }^{6,7}$ and with submaximal exercise. ${ }^{8}$ These findings, plus reports of low frequency electrical stimulation improving strength ${ }^{9}$ and high frequency stimulation seeming to have a deleterious effect, ${ }^{10}$ led to the recommendations of daily stretches in the lower extremities, encouragement of voluntary active exercise and the avoidance of eccentric activities, from the Muscular Dystrophy Campaign workshop. ${ }^{7}$ Other recommendations from this workshop included ankle foot orthoses (AFOs) to be used at night in conjunction with stretching. However, AFOs were not recommended to be used while the ambulant child is awake since they could compromise the ability to walk, but in the nonambulant child they should be used during the day to prevent contractures and deformities or if tenotomies were performed.

Surgical correction of contractures should be considered only in specific situations. Ambulatory patients utilize an equinus deformity to compensate for severe proximal weakness so Achilles tendon lengthening may lead to further weakness and subsequent wheelchair dependence. ${ }^{11}$ Some have advocated for intervention before significant contractures develop eliminating the need for intensive physical therapy postoperatively, as well as the need for physical therapy after the postoperative period. ${ }^{12}$ This approach is also felt to prolong brace-free ambulation and maintain lower extremity strength. Knee and hip contractors tend to occur concurrently after the child becomes wheelchair bound. These contractures can cause significant problems with positioning in bed and may lead to significant pain from muscle spasms and an increase in lumbar lordosis making tendon lengthening procedures important to improve the quality of life for these boys. ${ }^{11}$ Upper extremity contractures tend to develop during adolescence and typically do not require surgical intervention.

Besides contractures, scoliosis is another common orthopedic problem encountered in DMD, especially when the child losses the ability to walk. ${ }^{11}$ Braces are not effective and surgical correction becomes riskier over time due to cardiopulmonary weakness so early spinal stabilization when the curve reaches 30 degrees is often indicated. From a pulmonary standpoint, surgery has been recommended before vital capacity is below 30$35 \% .{ }^{13}$ Scoliosis exaggerates diaphragmatic weakness, reducing vital capacity and compounding the restrictive lung disease inspiratory muscle weakness causes. In addition, expiratory muscle weakness leads to an ineffective cough with causes atelectasis and pneumonia in the setting of restrictive lung disease. To decrease these complications, positive inspiratory pressure plus chest physiotherapy, most recently aided by the development of pneumatic vests, is recommended. ${ }^{13}$

Apart from scoliosis, the thoracic and abdominal muscle weakness that develops before diaphragmatic weakness leads to restrictive lung disease, which is seen as a diminution of maximal expiratory pressure typically after 7 years of age. ${ }^{13}$ Nocturnal hypoventilation and hypoxemia occurs when accessory muscle weakness develops and can be treated with noninvasive positive pressure ventilation (NPPV), which has 
been found improve survival, ${ }^{14}$ mental health, and social function. ${ }^{15}$ Once vital capacity drops to $12 \%$ predicted or less, boys with DMD tend to require daytime ventilatory assistance. ${ }^{16}$

\section{Corticosteroids}

Prednisone. In the 1960s, the initial studies on the use of steroids in DMD did not show favorable results. ${ }^{17,18}$ This finding continued to be reported in the early $1970 \mathrm{~s}^{18}$ until 1974 when Drachman, et al. ${ }^{17}$ reported a small study of fourteen boys with DMD who were treated with $2 \mathrm{mg} / \mathrm{kg} /$ day of prednisone for 2 to 3 months when the dose was then tapered to roughly $1.3 \mathrm{mg} / \mathrm{kg}$ on alternate days. There was no randomization and the study was not double blinded due to the obvious cushingoid effects seen within the first month of use. The boys were treated up to 28 months. It was felt that there was improvement or stabilization of functional status, which lasted for variable lengths of time, ranging from 3 to 28 months. Over $1 / 3$ of the boys treated with prednisone continued to deteriorate.

Thirteen years later further studies evaluating various dosages of prednisone were published. ${ }^{19,20}$ Drachman's group repeated their protocol following 16 boys for one or more years, during which time $1 / 2$ of this group became wheel chair bound and another quarter quickly became chair dependent shortly after discontinuation. ${ }^{17}$ Brooke's study used a dose of $1.5 \mathrm{mg} / \mathrm{kg}$ daily for 6 months in 33 boys, 6 of whom were wheelchair bound and could not perform the time function studies. ${ }^{19}$ The findings in this group were compared to that of historical controls and overall there appeared to be improvement in strength and function, but, as the authors point out, the study was neither randomized or blinded.

The first randomized, double-blind placebo controlled study was reported two years later comparing a 6-month trial of daily prednisone at doses of $0.75 \mathrm{mg} / \mathrm{kg}$ and $1.5 \mathrm{mg} / \mathrm{kg}$ in 103 boys. ${ }^{21}$ Strength testing, evaluated by an expanded 10-point score based on the grading system of the Medical Research Council (MRC), improved in the first 3 months and then stabilized compared to both placebo and historical control groups. These findings were also observed in the timed function tests, however, only one-half of the boys were tested in time to stand and two-thirds were tested in time to climb stairs. The third function tested, time to travel, was markedly skewed in favor of the lower dose prednisone group from the onset. The three statistically significant side effects were hair growth, cushingoid features and weight gain. Other side effects monitored for were behavioral changes, gastrointestinal symptoms, acne, easy bruising, glycosuria and cataracts.

The only other randomized, double-blinded, controlled, large-scale trial of prednisone in the literature to date $^{22}$ was published by the same group 2 years later when they compared doses of $0.3 \mathrm{mg} / \mathrm{kg} /$ day and $0.75 \mathrm{mg} /$ $\mathrm{kg} /$ day to placebo. ${ }^{23}$ Again, this was a 6-month study with initial increase in strength scores at 10 days for the low-dose group and up to 3-months in the higher dose group followed by the same rate of decline seen in the natural history group. Interestingly, the placebo control group also showed an increase in strength for the first month, followed by a more rapid decline than the historical controls. In the timed function tests, which again were only completed by $1 / 2$ to $2 / 3$ of the boys in the study, improvements in the high-dose group were seen, with less of a benefit for the lower dose. The statistically significant side effects were the same as the previous study, although they did not tend to occur until after the one-month evaluation, helping to decrease the chances of observer bias.

Since then, this same group reported their observations on daily versus alternate day dosing for 6 months after the trial comparing 0.75 to $1.5 \mathrm{mg} / \mathrm{kg} / \mathrm{day}$. They found daily dosing at $0.75 \mathrm{mg} / \mathrm{kg}$ maintained the effects longer than $2.5 \mathrm{mg} / \mathrm{kg}$ on alternate days. ${ }^{24}$ After completing one year in these two trials, 93 boys were placed on longterm prednisone at $0.75 \mathrm{mg} / \mathrm{kg} / \mathrm{day}$ and were found to have a slower progression of weakness compared to the natural history controls. ${ }^{25}$ The boys in the trial comparing 0.3 to $0.75 \mathrm{mg} / \mathrm{kg} / \mathrm{day}$ were followed up for a total of 18-moths, during which time the low-dose and placebo groups were given the addition of azathioprine and a placebo was added to the high-dose group. ${ }^{26}$ Interestingly, azathioprine did not improve strength, nor did it add any additional benefit to the low-dose of prednisone. The authors reported a sustained benefit from the highdose treatment group.

Several other prednisone dosing regimens have been examined in the ensuing years including $0.75 \mathrm{mg} / \mathrm{kg} / \mathrm{day}$ for the first 10 days of the month, ${ }^{1,27}$ the same dose for 10 days on and then 10 days off ${ }^{28}$ and $10 \mathrm{mg} / \mathrm{kg}$ given over two days weekly. ${ }^{29}$ Unfortunately, all of these studies either have very few patients (all $<20$ ) and only one was randomized. ${ }^{1}$ These various regimens have helped reduce the amount of side effects seen with the more recent studies also being able to better evaluate the effects of steroids on bone density. Alendronate, a bisphosphonate, has been shown to maintain bone mineral density in steroid-treated boys with DMD and was well tolerated. ${ }^{30}$ Vitamin D and calcium supplementation is recommended when using long-term steroids.

Prednisone has also been evaluated in boys as young as 2 to 4 years of age with the thought that the earlier the treatment is started the better chance of an effect. ${ }^{31}$ The ability to rise from a seated position was preserved longer in the 5 boys treated, but timed function tests were not significantly different. Prednisone has also been sug- 
gested to preserve cardiac function in a retrospective study. ${ }^{32}$

\section{Deflazacort}

In 1991, Mesa et al. ${ }^{33}$ and Angelini et al. ${ }^{34}$ reported the first double-blinded, placebo-controlled studies substituting Deflazacort (DF), an oxazoline derivative of prednisone, in place of prednisone. DF had been shown to have less side effects than prednisone and in this study caused a statistically significant increase in muscle strength and improvement in timed function tests. Three years later, Angelini et al. ${ }^{35}$, reported their findings from the only randomized, double-blinded, placebo controlled study of Deflazacort, ${ }^{22}$ where they compared $2 \mathrm{mg} / \mathrm{kg}$ DF on alternate days in 17 boys to 11 boys in the placebo group. DF was found to slow the progression of weakness compared to the placebo group with less side effects when compared to studies using prednisone. A retrospective study published in 2001 showed that boys treated with DF retained the ability to walk for a longer period of time compared to those not treated. ${ }^{36}$ Asymptomatic cataracts had developed in $1 / 3$ of the of the treatment group, a side effect that has very rarely been reported in any of the prednisone trials. DF is currently not available for use in the United States.

A comparison of two treatment protocols for DF, one using $0.6 \mathrm{mg} / \mathrm{kg} / \mathrm{day}$ for the first 20 days of the month and the other $0.9 \mathrm{mg} / \mathrm{kg} / \mathrm{day}$ (equivalent to $0.75 \mathrm{mg} / \mathrm{kg} /$ day of prednisone), showed the higher dose to be more effective in prolonging functional ability when compared with boys in both trials that either stopped taking DF or chose not to take it. ${ }^{37}$ Once again, however, approximately one-third of boys developed asymptomatic cataracts in the high-dose group. Unfortunately, a meta-analytic approach could not undertaken to further evaluate the beneficial effects of DF due to the heterogeneity in outcome measures of the published studies. ${ }^{38}$ Finally, like prednisone, DF has been shown, in a small, retrospective study, to preserve cardiac function in boys with DMD treated with DF for 3 years or more. ${ }^{39}$

\section{Prendisone versus Deflazacort}

In 2000, the first comparison study of prednisone and Deflazacort was published. ${ }^{40}$ This was a double-blinded, randomized trial comparing daily doses of $0.9 \mathrm{mg} / \mathrm{kg}$ DF to $0.75 \mathrm{mg} / \mathrm{kg}$ prednisone. Eighteen boys were treated with one or the other regimen and their findings after one year of treatment were compared with 7 ambulant boys, serving as the control. There was no statistically significant difference between the 2 treatment groups in both strength, as measured by MRC score, or function. However, one patient in the prednisone group who had lost ambulation dropped out of the study causing an improvement in the prednisone group's scores between the $9^{\text {th }}$ and $12^{\text {th }}$ month. The side effect profile was also similar in the two groups, including cataract formation, which was reported in two boys on DF and one taking prednisone.

In 2004 Manzur, et al., 22 published their Cochrane review of glucocorticoids' effects in boys DMD. As mentioned above, there have only been two large-scale, randomized, double-blinded, placebo controlled studies evaluating daily prednisone. The review combined these studies with a third study of 47 treated boys and found a significant improvement of strength, based on MRCbased scores for the 6-month period of the study. Unfortunately there are no good studies evaluating a longer duration of treatment. Only one study, which used DF, evaluated the primary outcome measure of prolongation of time to loss of ambulation, which the authors reported prolonged ambulation; ${ }^{35}$ however, according to the authors of the Cochrane review, the statistical technique was not appropriate. ${ }^{22}$ The authors also report that while $0.75 \mathrm{mg} / \mathrm{kg}$ of prednisone daily appears to improve strength and function for six months to two years, the potential harms are significant.

Review of the same studies by the Quality Standards Subcommittee of the American Academy of Neurology and the Practice Committee of the Child Neurology Society led them to publish a practice parameter recommending that prednisone at $0.75 \mathrm{mg} / \mathrm{kg} / \mathrm{day}$ should be offered as treatment with a gradual taper of the dose to as low as $0.3 \mathrm{mg} / \mathrm{kg} /$ day if side effects occur. ${ }^{41}$ They also advise that the discussion of steroid use be balanced with a dialogue of potential risks and that Deflazacort can be used in countries where it is available.

\section{Oxandrolone}

To evaluate other potential steroids as potential treatment in DMD, a pilot study of Oxandrolone, an anabolic steroid, was undertaken. ${ }^{42}$ This was a 6-month, randomized, double-blinded, placebo controlled study of 51 boys, 26 of whom randomized to the $0.1 \mathrm{mg} / \mathrm{kg} / \mathrm{d}$ oxandrolone group. There was no significant change in average strength tested manually, but there was one in quantitative muscle testing with some stabilization of the progression of weakness at 6 months. However, the placebo group did not weaken at rate expected from natural history studies, possibly due to a younger age of the boys in the study. There was no significant difference in the time function tests and no adverse effects.

\section{Mechanism of action}

The mechanism by which steroids seems to work in these boys is still being determined. When muscle biopsies were taken from boys who were treated with prednisone, there was a significant decrease in the total number of mononuclear cells per $\mathrm{mm}^{2}$ compared to the placebo group. This was due to a drop in $\mathrm{CD} 2+$ and $\mathrm{CD} 8+$ cells, as there was no significant difference in the CD4+, subgroup, B-cells, natural killer cells or macrophages. ${ }^{43}$ There was also no significant difference in the 
number of necrotic fibers. These findings suggest that at least one of prednisone's effect in DMD is due to a decrease in the number of cytotoxic/suppressor $\mathrm{T}$ cells. This would also lead to a decrease in cytokine activity. However, suppressing the inflammatory infiltrate is not sufficient by itself. When muscle biopsies were examine after the 6-month trial of prednisone versus azathioprine, there was no statistically significant difference in the lymphocyte population between the two groups, but the patients treated with azathioprine did not show a clinical improvement. ${ }^{44}$

Prednisone has also been shown to up-regulate upwards of 50 skeletal muscle genes, some important in regulating muscle hypertrophy. ${ }^{45}$ There was also an increase in protein markers for muscle regeneration. Prednisone has also been reported to shift the fiber type towards the fast-twitch fibers. ${ }^{45}$ On the other hand, prednisone was not found to up-regulate utrophin, a homologue of dystrophin, which binds to the sarcolemma in boys with DMD and may be able to maintain the dystrophin associated complex in high enough levels, ${ }^{46}$ nor was there an increase in calcineurin activity, which has been reported to be crucial for successful muscle regeneration in the $m d x$ mouse, the animal model of DMD. ${ }^{47}$ Cyclosporine, at $30 \mathrm{mg} / \mathrm{kg} / \mathrm{day}$, was used to inhibit calcineurin signal transduction pathway and treated mice were found to have a lower muscle mass and generated less isometric force than control mice. There was also an increase in connective tissue and cellular infiltrate with a loss of viable muscle fibers. However, when one-third of the dose was given to $m d x$ mice, there was a significant improvement in the pathologic findings compared to the placebo group and prevention of exercise-induced loss of muscle strength. ${ }^{48}$ An even smaller dose $(5 \mathrm{mg} / \mathrm{kg} / \mathrm{d})$ given to 15 boys with DMD increased force generation in the tibialis anterior. ${ }^{49}$

It has also been shown in the $m d x$ mouse that DF at $1.2 \mathrm{mg} / \mathrm{kg}$ injected subcutaneously daily was shown to promote the proliferation and/or fusion of muscle precursor cells during repair in response to injury, as well as long-term growth of all intact fibers. ${ }^{50}$ Prednisone was found to only promote an increase in diameter of fibers, but not the growth of regenerating myotubes.

\section{Supplements}

Nutritional supplements are being used more frequently either in conjunction with medications or on their own. Several supplements have been evaluated for efficacy in DMD. Two recent studies have evaluated the use of creatine monohydrate, an amino acid found in muscle that stores energy as phosphocreatine for immediate use. It has been shown to increase strength in patients with neuromuscular disorders ${ }^{51}$ as well as reduce necrosis in the $m d x$ mouse. ${ }^{52}$ A double-blinded, randomized, cross-over study of creatine, in boys with
DMD, for 4 months showed an increase in handgrip strength and fat free mass. ${ }^{53}$ One-half of the boys in the study had been taking corticosteroids for over 6 months and interestingly, there was no statistically significant difference of strength between this group and the boys not treated with corticosteroids and the decline in strength over the 10 month study period was similar. In fact, the beneficial effects of creatine were found to be independent of corticosteroids use. The other study evaluated creatine to glutamine and placebo in steroid-naïve boys with DMD in a 6-month, double-blinded trial. ${ }^{4}$ Supplementation with glutamine is felt to prevent muscle catabolism. This study found no statistically significant effect of either therapy on manual and quantitative muscle strength, although there appeared to be a trend towards less deterioration in all other outcome measures. The authors postulate that this was due to the fact that the placebo group did not deteriorate in strength over the study period.

$\mathrm{L}$-arginine is amino acid that enhances nitric oxide synthesis. Nitric oxide synthetase (NOS) is found under the sarcolemma, as is utrophin, possibly implying a correlation between the expression of utrophin and activity of NOS. ${ }^{54}$ In fact, when wild type and $m d x$ mice were treated with nitric oxide donor or L-arginine, utrophin expression increased. ${ }^{55}$ In the $m d x$ mouse, L-arginine supplementation was found to lead to less muscle necrosis, smaller amounts of collagen and fatty replacement without a change in the number of fibers with central nuclei, signifying the reduction of necrosis was not due to myofiber regeneration. ${ }^{54}$ It has also been shown in this mouse model that $\mathrm{L}$-arginine treated $m d x$ muscle were less susceptible to contraction-induced injury. ${ }^{56}$

Finally, a combination of creatine monohydrate, conjugated linoleic acid, alpha-lipoic acid and betahydroxy-beta-methylbutyrate (HMB) improved strength and decreased fatigue in the $m d x$ mouse. ${ }^{57}$ This combination was better than any individual supplement alone as well as prednisone alone, although all had some benefit. The combination with prednisone provided the best results.

\section{Myostatin}

Myostatin is a member of the Transforming Growth Factor-beta family of signaling molecules expressed predominantly in muscle. ${ }^{58}$ Blocking myostatin in mice resulted in excessive growth and increased force generation of muscle. ${ }^{59}$ In fact, A young boy with exaggerated muscle hypertrophy was found to have a mutation in the myostatin gene. ${ }^{60}$ In the $m d x$ mouse, blocking myostatin by injecting blocking antibodies lead to an increase in body weight as well as muscle mass, size and strength. ${ }^{61}$ When the $m d x$ mouse was crossed with mice with a myostatin null mutation, the $m d x$ mice that were homozygous for the myostatin mutation were larger and 
more muscular than those mice that did not carry the myostatin mutation. ${ }^{62}$ Muscle fiber size was increased in the mice with the null mutation and there was decreased amount of fibrosis and fatty infiltration. CPK was similar in both groups as was central nuclei. Finally, $m d x$ mice with a dominant negative form of myostatin receptor were also found to have larger muscles and their muscle fibers had a greater resistance to exercise-induced injury. ${ }^{63}$ It was also discovered in this study that myoblast transplantation was significantly more successful in these mice than those $m d x$ mice with a normal myostatin receptor gene, giving new possibilities to the use of myoblast transfer in the treatment of DMD.

\section{Cell therapy}

Myoblast transplantation as a potential therapeutic approach arose from the basic property of muscle being a multinucleate syncytium. Studies in the 1970's showed that mononucleated muscle cells, when directly injected into mature muscle, fuse with mature muscle and thus contribute new nuclei to the syncytium. ${ }^{64}$ This was recognized as a potential way to introduce normal alleles into multinucleated muscle fibers composed entirely of nuclei bearing genetic defects and thus as a way to treat, genetically, hereditary muscle diseases. While the concept is appealing, the procedure has come up against several obstacles. After studies established the possibility of myoblast transplantation in normal mice, ${ }^{65,66}$ myoblast transplantation was shown to convert dystrophinnegative fibers to dystrophin-positive fibers in the $m d x$ mouse. ${ }^{67}$ Several clinical trials where myoblasts were injected into various muscles of boys with DMD were then undertaken with poor results. In one study, there was no improvement in strength in those boys who received injections in the biceps once a month for six months. ${ }^{68}$ Half of the boys received cyclosporine for immunosuppression after the transplant, but even in this group there was no improvement in strength nor did it provide a beneficial effect on the transfer. The researchers were unable to determine the percentage of donor dystrophin present. In another study where myoblasts were injected into the tibialis anterior in DMD boys, who were then treated with cyclosporine for 7 months, there was an increase in force generation in both the treated and untreated leg, suggesting a beneficial effect of cyclosporine. ${ }^{69}$ The study also found that a small amount of donor cells survived and produced dystrophin, without altering strength. Another group reported a positive effect after transfer therapy, with the presence of donor dystrophin up to 6 years after the transfer. ${ }^{70,71}$ This finding has not be validated. ${ }^{72}$

In 2002, Gussoni, et al. ${ }^{73}$ reported the case of a 12 year-old boy with DMD who had a bone marrow transplant for severe combined immunodeficiency at the age of one year. The muscle biopsy from this patient showed the presence of donor nuclei in less than one percent of the muscle fibers, demonstrating the ability of exogenous bone marrow cells to fuse into skeletal muscle and last more than a decade. This finding had been reported earlier after $m d x$ mice underwent a bone marrow biopsy and were found to a have a small number of dystrophinpositive fibers from the donor, 8-12 weeks after the procedure. $^{74,75}$ Revertant fibers, fibers producing a shortened form of dystrophin by skipping the mutation in $m d x$ mice in exon $23,{ }^{76}$ may lead to false results, so researchers used another mouse model with a dystrophinopathy due to a premature stop codon in exon 53 of the dystrophin gene. ${ }^{77}$ These mice are known to have a very small number of revertant fibers. After a bone marrow transplant, clusters of fibers that were dystrophin-positive were found in all the animals. However, the dystrophinpositive fibers only averaged a total of $0.25 \%$ of all fibers after 10 months, even though in the rest of the organs the percentage of donor cells was greater than $85 \%$.

Being able to deliver myogenic cells systemically, versus injecting into the affected muscles, will greatly improve the use of this therapy if the efficiency of myogenesis from bone marrow derived cells can be increased. The other obstacle that needs to be addressed is the immunologic response of the host body to the newly formed dystrophin in a system where the protein was previously absent. This problem has also been causing difficulty in gene therapy.

\section{Gene therapy}

Dystrophin is the largest gene in the human genome composed of 2.6 million base pairs and containing 79 exons. Because of it's large size it is highly prone to spontaneous mutations. Approximately $60 \%$ of boys with DMD will have a deletion of one or more exons and another 5-10\% have a duplication. The remaining 30$35 \%$ are due to point mutations. If the mutation leads to a shift in the reading frame, dystrophin will not be produced and the child will have Duchenne phenotype. If the reading frame is not disrupted, an abnormal dystrophin will be created and the child will have the milder phenotype, Becker muscular dystrophy (BMD).

Over the years, various strategies have been examined for use as a treatment in DMD, if not a cure. The initial adenoviral vectors created were too small to fit the entire coding sequence for dystrophin. The vectors were then gutted, removing all adenoviral genes, allowing the necessary DNA to be inserted. ${ }^{78}$ This vector had added benefits of a reduced host immune response due to the decreased viral protein load and increased the persistence of transgene expression in the muscle. Two significant problems still remained, the virus is too large to cross the extracellular matrix to get to the muscle fibers and the myofibers have few receptors for adenoviruses to attach to. ${ }^{79}$ Upregulating adenovirus receptors has been shown 
to improve gene transfer efficiency in transgenic mice, allowing for reduced viral vector loads. ${ }^{80}$ Unfortunately, there is currently no known way of applying this to humans. Herpes simplex virus has been used since it can naturally hold a large insert, but similar problems to those seen in the adenoviral vectors were encountered, although newer generations have been created causing less of an immune reaction and longer transgene expression time. ${ }^{81,82}$

Other viruses have also been considered as alternatives to those mentioned above. To be useful, smaller sections of the dystrophin gene would need to be inserted. Mild phenotypes have been associated with deletions near the $\mathrm{N}$-terminal domain and the C-terminal domain does not appear to be required for the assembly of the dystrophinglycoprotein complex. $^{79}$ Therefore, minidystrophin genes can be constructed to reduce the severity of the disorder, converting a patient with Duchenne phenotype to that of a Becker phenotype. ${ }^{83}$ This has been shown to be successful in the $m d x$ mouse. ${ }^{84}$

Adeno-associated virus (AAV) is now used more commonly for gene transfer given its nonpathogenicity, broad tropism and infectivity and long-term persistence. ${ }^{85}$ Although nonselective tissue transduction may make it more difficult to utilize, certain serotypes have a natural tropism for muscle, making them attractive candidates for the treatment of muscular dystrophies. These vectors, containing micro and mini-dystrophin gene constructs have already been tested in the $m d x$ mouse, with effects lasting up to six months. ${ }^{79}$ More recently, high capacity vectors have been created allowing for fulllength delivery of dystrophin, although certain properties of these vectors make them unsuitable for long-term genetic correction. ${ }^{86}$ Lentiviral vectors, derived from a small family of retroviruses, have been found to stably transduce post-mitotic cells with expression lasting up to 2 months with no associated immune response. ${ }^{87}$

Synthetic, non-infectious DNA plasmid vectors have also been studied since they can also hold large inserts. Initial studies in the mdx mouse ${ }^{88}$ and the dog model ${ }^{89}$ were promising, so nine boys with DMD or BMD underwent a phase I study. ${ }^{89}$ The dystrophin plasmid was injected in the radialis and a muscle biopsy was taken 3 weeks later. The vector was detected in all patients and in 6 of the 9 boys, dystrophin expression was found. Although expression was low, there was complete sarcolemmal staining in $6 \%$ of the fibers and partial staining in almost $30 \%$. The therapy was well tolerated and there was no evidence of anti-DNA antibodies or any antidystrophin immune response. The authors report that they are currently evaluating the feasibility of intravascular administration of these plasmids to be able to treat the disease systemically, rather than focally.

Other methods to alter the dystrophin gene have been studied. Chimeraplasts, a double-stranded DNA-RNA hybrid molecule, repairs genes through natural DNA repair mechanisms. This technique is possible only for point mutations. There have been promising results in $m d x$ myoblasts, ${ }^{80}$ as well as in the $m d x$ mouse where dystrophin-positive fibers were found clustered around the site of the intramuscular injection of the chimeraplasts. ${ }^{90}$ Since this method is only useful for those boys with a point mutation, only a minority of boys may benefit from this technique. Although the effects are cumulative and permanent, the method is still inefficient and dependent of the rate of repair activity of the host cell. $^{79}$

Finally, taking a cue from revertant fibers, exon-skipping was considered as another possible mechanism in reducing the severity of DMD, as it can turn an in-frame mutation to an out-of-frame mutation. Antisense oligoribonucleotides (AONs) have been shown to be a safe and efficient method to induce this process in the dystrophin gene. ${ }^{91}$ Intramuscular injections in the $\mathrm{mdx}$ mouse led to persistent production of dystrophin at normal levels in large numbers of muscle fibers. ${ }^{92}$ Also, the mice showed functional improvement of the treated muscle. Dystrophin expression was enhanced with repeated injections and no immune response was elicited. It has been estimated that approximately $70 \%$ of boys with DMD caused by intragenic deletions could be helped by this approach. ${ }^{93}$ In fact, two European clinical trials are getting ready to begin. ${ }^{93}$ As with any gene therapy, there is a concern that once boys who are not producing fulllength dystrophin start to do so they will have an immunologic response to the new protein. However, it has been pointed out that many DMD patients express rare revertant fibers, which increase in number with age, and do not attract attention of the immune system. ${ }^{94}$ One advantage to this therapy is that it corrects all isoforms of dystrophin and maintains the original tissue-specific gene regulation. ${ }^{79}$ Interestingly, some feel that since no permanent genetic changes are induced and the site of action for these molecules is the gene transcript and not the gene, this should not be considered a form of gene therapy. ${ }^{95}$

\section{Aminoglycosides}

Aminoglycosides, such as gentamicin, can suppress premature stop codons by causing a relaxation in codon recognition, making the use of this class of drug another possible option. Again, this treatment would only be available for a small percentage of boys afflicted with DMD. Since the mdx mouse's point mutation on chromosome 23 leads to a premature stop codon, gentamicin was tried and successfully restored functional dystrophin. ${ }^{96}$ Unfortunately, results have not been as promising in clinical trials. ${ }^{97}$ Most likely these findings are partially due to the our inability to deliver adequate amounts of the drug due to it's toxicity. A new class of drugs, which 
targets nonsense mutations, has recently been introduced and studies are planned on evaluating the first drug in this class, PTC124, in boys with DMD.

\section{CONCLUSION}

While investigators are developing ways to utilize stem cell and gene therapies to hopefully cure DMD, others are trying to find other methods of at least stabilizing the progressive weakness that develops in this condition. In the mean time, therapeutic intervention, in conjunction with the use of orthotics, orthopedic manipulation and assistance with respiratory compromise that develops can help improve a child's quality of life and hopefully delay death, which is typically due to respiratory or cardiac failure. A thorough conversation about the use of corticosteroids, outlining their potential risks and benefits is recommended. Also, nutrional supplements, which are safe and usually well tolerated, should be discussed with the patient and his family.

\section{REFERENCES}

1. Beenakker EA, Maurits NM, Fock JM, Brouwer OF, van der Hoeven JH. Functional ability and muscle force in healthy children and ambulant Duchenne muscular dystrophy patients. Eur J Paediatr Neurol 2005.

2. Kroksmark AK, Beckung E, Tulinius M. Muscle strength and motor function in children and adolescents with spinal muscular atrophy II and III. Eur J Paediatr Neurol 5:191-198, 2001.

3. Merlini L, Bertini E, Minetti C, Mongini T, Morandi L, Angelini $\mathrm{C}$, et al. Motor function-muscle strength relationship in spinal muscular atrophy. Muscle Nerve 29:548-552, 2004.

4. Escolar DM, Buyse G, Henricson E, Leshner R, Florence J, Mayhew J, et al. CINRG randomized controlled trial of creatine and glutamine in Duchenne muscular dystrophy. Ann Neurol 58:151$155,2005$.

5. Brooke MH, Fenichel GM, Griggs RC, Mendell JR, Moxley R, Florence J, et al. Duchenne muscular dystrophy: patterns of clinical progression and effects of supportive therapy. Neurology 39:475481, 1989.

6. Ansved T. Muscular dystrophies: influence of physical conditioning on the disease evolution. Curr Opin Clin Nutr Metab Care 6:435-439, 2003.

7. Eagle M. Report on the muscular dystrophy campaign workshop: exercise in neuromuscular diseases Newcastle, January 2002. Neuromuscul Disord 12:975-983, 2002.

8. de Lateur BJ, Giaconi RM. Effect on maximal strength of submaximal exercise in Duchenne muscular dystrophy. Am J Phys Med 58:26-36, 1979.

9. Scott OM, Hyde SA, Vrbova G, Dubowitz V. Therapeutic possibilities of chronic low frequency electrical stimulation in children with Duchenne muscular dystrophy. J Neurol Sci 95:171-182, 1990.

10. Dubowitz V. Responses of diseased muscle to electrical and mechanical intervention. Ciba Found Symp 138:240-255, 1988.

11. Do T. Orthopedic management of the muscular dystrophies. Curr Opin Pediatr 14:50-53, 2002.

12. Bach JR. The historical role of the physiatrist in the management of Duchenne muscular dystrophy. A commentary. Am J Phys Med Rehabil 75:239-241, 1996.

13. Schramm CM. Current concepts of respiratory complications of neuromuscular disease in children. Curr Opin Pediatr 12:203-207, 2000.

14. Bach JR, Ishikawa Y, Kim H. Prevention of pulmonary morbidity for patients with Duchenne muscular dystrophy. Chest 112:10241028, 1997.
15. Simonds AK, Muntoni F, Heather S, Fielding S. Impact of nasal ventilation on survival in hypercapnic Duchenne muscular dystrophy. Thorax 53:949-952, 1998.

16. Birnkrant DJ, Pope JF, Eiben RM. Management of the respiratory complications of neuromuscular diseases in the pediatric intensive care unit. J Child Neurol 14:139-143, 1999.

17. Drachman DB, Toyka KV, Myer E. Prednisone in Duchenne muscular dystrophy. Lancet 2:1409-1412, 1974.

18. Siegel IM, Miller JE, Ray RD. Failure of corticosteroid in the treatment of Duchenne (pseudo-hypertrophic) muscular dystrophy. Report of a clinically matched three year double-blind study. IMJ Ill Med J 145:32-33 passim, 1974.

19. Brooke MH, Fenichel GM, Griggs RC, Mendell JR, Moxley RT 3rd, Miller JP, et al. Clinical investigation of Duchenne muscular dystrophy. Interesting results in a trial of prednisone. Arch Neurol 44:812-827, 1987.

20. DeSilva S, Drachman DB, Mellits D, Kuncl RW. Prednisone treatment in Duchenne muscular dystrophy. Long-term benefit. Arch Neurol 44:818-822, 1987.

21. Mendell JR, Moxley RT, Griggs RC, Brooke MH, Fenichel GM, Miller JP, et al. Randomized, double-blind six-month trial of prednisone in Duchenne's muscular dystrophy. N Engl J Med 320: 1592-1597, 1989.

22. Manzur AY, Kuntzer T, Pike M, Swan A. Glucocorticoid corticosteroids for Duchenne muscular dystrophy. Cochrane Database Syst Rev 2004(2): p. CD003725.

23. Griggs RC, Moxley RT 3rd, Mendell JR, Fenichel GM, Brooke $\mathrm{MH}$, Pestronk A, et al. Prednisone in Duchenne dystrophy. A randomized, controlled trial defining the time course and dose response. Clinical Investigation of Duchenne Dystrophy Group. Arch Neurol 48:383-388, 1991.

24. Fenichel GM, Mendell JR, Moxley RT 3rd, Griggs RC, Brooke $\mathrm{MH}$, Miller JP, et al. A comparison of daily and alternate-day prednisone therapy in the treatment of Duchenne muscular dystrophy. Arch Neurol 48:575-579, 1991.

25. Fenichel GM, Florence JM, Pestronk A, Mendell JR, Moxley RT 3rd, Griggs RC, et al. Long-term benefit from prednisone therapy in Duchenne muscular dystrophy. Neurology 41:1874-1877, 1991.

26. Griggs RC, Moxley RT 3rd, Mendell JR, Fenichel GM, Brooke $\mathrm{MH}$, Pestronk A, et al. Duchenne dystrophy: randomized, controlled trial of prednisone (18 months) and azathioprine (12 months). Neurology 43(3 Pt 1):520-527, 1993.

27. Sansome A, Royston P, Dubowitz V. Steroids in Duchenne muscular dystrophy; pilot study of a new low-dosage schedule. $\mathrm{Neu}$ romuscul Disord 3:567-569, 1993.

28. Kinali M, Mercuri E, Main M, Muntoni F, Dubowitz V. An effective, low-dosage, intermittent schedule of prednisolone in the long-term treatment of early cases of Duchenne dystrophy. Neuromuscul Disord 12(Suppl 1):S169-S174, 2002.

29. Connolly AM, Schierbecker J, Renna R, Florence J. High dose weekly oral prednisone improves strength in boys with Duchenne muscular dystrophy. Neuromuscul Disord 12:917-925, 2002.

30. Hawker GA, Ridout R, Harris VA, Chase CC, Fielding LJ, Biggar WD. Alendronate in the treatment of low bone mass in steroidtreated boys with Duchennes muscular dystrophy. Arch Phys Med Rehabil 86:284-288, 2005.

31. Merlini L, Cicognani A, Malaspina E, Gennari M, Gnudi S, Talim B, et al. Early prednisone treatment in Duchenne muscular dystrophy. Muscle Nerve 27:222-7, 2003.

32. Markham LW, Spicer RL, Khoury PR, Wong BL, Mathews KD, Cripe LH. Steroid Therapy and Cardiac Function in Duchenne Muscular Dystrophy. Pediatr Cardiol 2005.

33. Mesa LE, Dubrovsky AL, Corderi J, Marco P, Flores D. Steroids in Duchenne muscular dystrophy-deflazacort trial. Neuromuscul Disord 1:261-266, 1991.

34. Angelini C, Pegoraro E, Perini F, Turella E, Intino M, Pini A, et al. A trial with a new steroid in Duchenne Muscular Dystrophy. In: Muscular dystrophy research (Angelini C, Danieli GA, Fontanari D, eds.), pp 173-179. New York, NY: Elsevier, 1991.

35. Angelini C, Pegoraro E, Turella E, Intino MT, Pini A, Costa C. Deflazacort in Duchenne dystrophy: study of long-term effect. Muscle Nerve 17:386-391, 1994.

36. Biggar WD, Gingras M, Fehlings DL, Harris VA, Steele CA. 
Deflazacort treatment of Duchenne muscular dystrophy. J Pediatr 138:45-50, 2001

37. Biggar WD, Politano L, Harris VA, Passamano L, Vajsar J, Alman B, et al. Deflazacort in Duchenne muscular dystrophy: a comparison of two different protocols. Neuromuscul Disord 14(8-9):476482, 2004.

38. Campbell C, Jacob P. Deflazacort for the treatment of Duchenne Dystrophy: a systematic review. BMC Neurol 3:7, 2003.

39. Silversides CK, Webb GD, Harris VA, Biggar DW. Effects of deflazacort on left ventricular function in patients with Duchenne muscular dystrophy. Am J Cardiol 91:769-772, 2003.

40. Bonifati MD, Ruzza G, Bonometto P, Berardinelli A, Gorni K, Orcesi S, et al. A multicenter, double-blind, randomized trial of deflazacort versus prednisone in Duchenne muscular dystrophy. Muscle Nerve 23:1344-1347, 2000.

41. Moxley RT 3rd, Ashwal S, Pandya S, Connolly A, Florence J, Mathews K, et al. Practice parameter: corticosteroid treatment of Duchenne dystrophy: report of the Quality Standards Subcommittee of the American Academy of Neurology and the Practice Committee of the Child Neurology Society. Neurology 64:13-20, 2005.

42. Fenichel GM, Griggs RC, Kissel J, Kramer TI, Mendell JR, Moxley RT, et al. A randomized efficacy and safety trial of oxandrolone in the treatment of Duchenne dystrophy. Neurology 56:1075-1079, 2001.

43. Kissel JT, Burrow KL, Rammohan KW, Mendell JR. Mononuclear cell analysis of muscle biopsies in prednisone-treated and untreated Duchenne muscular dystrophy. CIDD Study Group. Neurology 41:667-672, 1991

44. Kissel JT, Lynn DJ, Rammohan KW, Klein JP, Griggs RC, Moxley RT 3rd, et al. Mononuclear cell analysis of muscle biopsies in prednisone- and azathioprine-treated Duchenne muscular dystrophy. Neurology 43(3 Pt 1):532-536, 1993.

45. Fisher I, Abraham D, Bouri K, Hoffman EP, Muntoni F, Morgan J. Prednisolone-induced changes in dystrophic skeletal muscle. Faseb J 19:834-836, 2005.

46. Tinsley JM, Blake DJ, Pearce M, Knight AE, Kendrick-Jones J, Davies KE. Dystrophin and related proteins. Curr Opin Genet Dev 3:484-490, 1993.

47. Stupka N, Gregorevic P, Plant DR, Lynch GS. The calcineurin signal transduction pathway is essential for successful muscle regeneration in $\mathrm{mdx}$ dystrophic mice. Acta Neuropathol (Berl) 107: 299-310, 2004.

48. De Luca A, Nico B, Liantonio A, Didonna MP, Fraysse B, Pierno $\mathrm{S}$, et al. A multidisciplinary evaluation of the effectiveness of cyclosporine a in dystrophic mdx mice. Am J Pathol 166:477-489, 2005.

49. Sharma KR, Mynhier MA, Miller RG. Cyclosporine increases muscular force generation in Duchenne muscular dystrophy. Neurology 43(3 Pt 1):527-532, 1993.

50. Anderson JE, McIntosh LM, Poettcker R. Deflazacort but not prednisone improves both muscle repair and fiber growth in diaphragm and limb muscle in vivo in the mdx dystrophic mouse. Muscle Nerve 19:1576-1585, 1996.

51. Tarnopolsky M, Martin J. Creatine monohydrate increases strength in patients with neuromuscular disease. Neurology 52:854-857, 1999.

52. Passaquin AC, Renard M, Kay L, Challet C, Mokhtarian A, Wallimann T, et al. Creatine supplementation reduces skeletal muscle degeneration and enhances mitochondrial function in $\mathrm{mdx}$ mice. Neuromuscul Disord 12:174-182, 2002.

53. Tarnopolsky MA, Mahoney DJ, Vajsar J, Rodriguez C, Doherty TJ, Roy BD, et al. Creatine monohydrate enhances strength and body composition in Duchenne muscular dystrophy. Neurology 62:1771-1777, 2004.

54. Voisin V, Sebrie C, Matecki S, Yu H, Gillet B, Ramonatxo M, et al. L-arginine improves dystrophic phenotype in mdx mice. Neurobiol Dis 20:123-130, 2005.

55. Chaubourt E, Voisin V, Fossier P, Baux G, Israel M, De La Porte S. Muscular nitric oxide synthase (muNOS) and utrophin. J Physiol Paris 96(1-2):43-52, 2002.
56. Barton ER, Morris L, Kawana M, Bish LT, Toursel T. Systemic administration of L-arginine benefits mdx skeletal muscle function. Muscle Nerve 2005.

57. Payne ET, Yasuda N, Bourgeois JM, Devries MC, Rodriguez MC, Yousuf J, et al. Nutritional therapy improves function and complements corticosteroid intervention in mdx mice. Muscle Nerve 2005.

58. Patel K, Amthor H. The function of Myostatin and strategies of Myostatin blockade-new hope for therapies aimed at promoting growth of skeletal muscle. Neuromuscul Disord 15:117-126, 2005.

59. McPherron AC, Lawler AM, Lee SJ. Regulation of skeletal muscle mass in mice by a new TGF-beta superfamily member. Nature 387:83-90, 1997.

60. Schuelke M, Wagner KR, Stolz LE, Hubner C, Riebel T, Komen $\mathrm{W}$, et al. Myostatin mutation associated with gross muscle hypertrophy in a child. $N$ Engl J Med 350:2682-2688, 2004.

61. Bogdanovich S, Krag TO, Barton ER, Morris LD, Whittemore LA, Ahima RS, et al. Functional improvement of dystrophic muscle by myostatin blockade. Nature 420:418-421, 2002.

62. Wagner KR, McPherron AC, Winik N, Lee SJ. Loss of myostatin attenuates severity of muscular dystrophy in mdx mice. Ann Neurol 52:832-836, 2002.

63. Benabdallah BF, Bouchentouf M, Tremblay JP. Improved success of myoblast transplantation in mdx mice by blocking the myostatin signal. Transplantation 79:1696-1702, 2005.

64. Partridge TA, Grounds M, Sloper JC. Evidence of fusion between host and donor myoblasts in skeletal-muscle grafts. Nature 273: 306-308, 1978.

65. Watt DJ, Lambert K, Morgan JE, Partridge TA, Sloper JC. Incorporation of donor muscle precursor cells into an area of muscle regeneration in the host mouse. J Neurol Sci 57(2-3):319-331, 1982.

66. Watt DJ, Morgan JE, Partridge TA. Use of mononuclear precursor cells to insert allogeneic genes into growing mouse muscles. Muscle Nerve 7:741-750, 1984.

67. Partridge TA, Morgan JE, Coulton GR, Hoffman EP, Kunkel LM Conversion of mdx myofibres from dystrophin-negative to -positive by injection of normal myoblasts. Nature 337:176-179, 1989.

68. Mendell JR, Kissel JT, Amato AA, King W, Signore L, Prior TW, et al. Myoblast transfer in the treatment of Duchenne's muscular dystrophy. N Engl J Med 333:832-838, 1995.

69. Miller RG, Sharma KR, Pavlath GK, Gussoni E, Mynhier M, Lanctot AM, et al. Myoblast implantation in Duchenne muscular dystrophy: the San Francisco study. Muscle Nerve 20:469-478, 1997.

70. Law PK. Myoblast transfer therapy. Lancet 341:8839, 1993.

71. Law PK, Goodwin TG, Fang Q, Hall TL, Quinley T, Vastagh G, et al. First human myoblast transfer therapy continues to show dystrophin after 6 years. Cell Transplant 6:95-100, 1997.

72. Partridge T. Myoblast transplantation. Neuromuscul Disord 12(Suppl 1):S3-S6, 2002.

73. Gussoni E, Bennett RR, Muskiewicz KR, Meyerrose T, Nolta JA, Gilgoff I, et al. Long-term persistence of donor nuclei in a Duchenne muscular dystrophy patient receiving bone marrow transplantation. J Clin Invest 110:807-814, 2002.

74. Bittner RE, Schofer C, Weipoltshammer K, Ivanova S, Streubel B, Hauser E, et al. Recruitment of bone-marrow-derived cells by skeletal and cardiac muscle in adult dystrophic mdx mice. Anat Embryol (Berl) 199:391-396, 1999.

75. Gussoni E, Soneoka Y, Strickland CD, Buzney EA, Khan MK, Flint AF, et al. Dystrophin expression in the mdx mouse restored by stem cell transplantation. Nature 401:390-394, 1999.

76. Wilton SD, Dye DE, Blechynden LM, Laing NG. Revertant fibres: a possible genetic therapy for Duchenne muscular dystrophy? Neuromuscul Disord 7:329-335, 1997.

77. Ferrari G, Mavilio F. Myogenic stem cells from the bone marrow: a therapeutic alternative for muscular dystrophy? Neuromuscul Disord 12(Suppl 1):S7-S10, 2002.

78. Kochanek S, Clemens PR, Mitani K, Chen HH, Chan S, Caskey CT. A new adenoviral vector: Replacement of all viral coding sequences with $28 \mathrm{~kb}$ of DNA independently expressing both full-length dystrophin and beta-galactosidase. Proc Natl Acad Sci U S A 93:5731-5736, 1996. 
79. van Deutekom JC, van Ommen GJ. Advances in Duchenne muscular dystrophy gene therapy. Nat Rev Genet 4:774-783, 2003.

80. Dubowitz V. Special Centennial Workshop- 101st ENMC International Workshop: Therapeutic Possibilities in Duchenne Muscular Dystrophy, 30th November-2nd December 2001, Naarden, The Netherlands. Neuromuscul Disord 12:421-431, 2002.

81. Akkaraju GR, Huard J, Hoffman EP, Goins WF, Pruchnic R, Watkins SC, et al. Herpes simplex virus vector-mediated dystrophin gene transfer and expression in MDX mouse skeletal muscle. J Gene Med 1:280-289, 1999.

82. Huard J, Krisky D, Oligino T, Marconi P, Day CS, Watkins SC, et al. Gene transfer to muscle using herpes simplex virus-based vectors. Neuromuscul Disord 7:299-313, 1997.

83. Harper SQ, Hauser MA, DelloRusso C, Duan D, Crawford RW, Phelps SF, et al. Modular flexibility of dystrophin: implications for gene therapy of Duchenne muscular dystrophy. Nat Med 8:253$261,2002$.

84. Wang B, Li J, Xiao X. Adeno-associated virus vector carrying human minidystrophin genes effectively ameliorates muscular dystrophy in mdx mouse model. Proc Natl Acad Sci U S A 97:13714$13719,2000$.

85. Athanasopoulos T, Graham IR, Foster H, Dickson G. Recombinant adeno-associated viral (rAAV) vectors as therapeutic tools for Duchenne muscular dystrophy (DMD). Gene Ther 11(Suppl 1): S109-S121, 2004.

86. Goncalves MA, van Nierop GP, Tijssen MR, Lefesvre P, KnaanShanzer S, van der Velde I, et al. Transfer of the full-length dystrophin-coding sequence into muscle cells by a dual highcapacity hybrid viral vector with site-specific integration ability. J Virol 79:3146-3162, 2005.

87. Kapsa R, Kornberg AJ, Byrne E. Novel therapies for Duchenne muscular dystrophy. Lancet Neurol 2:299-310, 2003.

88. Braun S, Thioudellet C, Rodriguez P, Ali-Hadji D, Perraud F, Accart N, et al. Immune rejection of human dystrophin following intramuscular injections of naked DNA in mdx mice. Gene Ther 7:1447-1457, 2000.

89. Romero NB, Braun S, Benveniste O, Leturcq F, Hogrel JY, Morris GE, et al. Phase I study of dystrophin plasmid-based gene therapy in Duchenne/Becker muscular dystrophy. Hum Gene Ther 15: 1065-1076, 2004.

90. Rando TA, Disatnik MH, Zhou LZ. Rescue of dystrophin expression in mdx mouse muscle by RNA/DNA oligonucleotides. Proc Natl Acad Sci U S A 97:5363-5368, 2000.

91. van Deutekom JC. Gene therapy: the 'pro-sense' approach to Duchenne muscular dystrophy. Eur J Hum Genet 13:518-519, 2005.

92. Lu QL, Mann CJ, Lou F, Bou-Gharios G, Morris GE, Xue SA, et al. Functional amounts of dystrophin produced by skipping the mutated exon in the mdx dystrophic mouse. Nat Med 9:10091014, 2003.

93. Muntoni F, Bushby K, van Ommen G. 128th ENMC International Workshop on 'Preclinical optimization and Phase I/II Clinical Trials Using Antisense Oligonucleotides in Duchenne Muscular Dystrophy' 22-24 October 2004, Naarden, The Netherlands. Neuromuscul Disord 15:450-457, 2005.

94. Wells DJ, Ferrer A, Wells KE. Immunological hurdles in the path to gene therapy for Duchenne muscular dystrophy. Expert Rev Mol Med 2002:1-23, 2002.

95. Wilton SD, Fletcher S. Antisense oligonucleotides in the treatment of Duchenne muscular dystrophy: Where are we now? Neuromuscul Disord 15:399-402, 2005.

96. Barton-Davis ER, Cordier L, Shoturma DI, Leland SE, Sweeney HL. Aminoglycoside antibiotics restore dystrophin function to skeletal muscles of mdx mice. J Clin Invest 104:375-381, 1999.

97. Wagner KR, Hamed S, Hadley DW, Gropman AL, Burstein AH, Escolar DM, et al. Gentamicin treatment of Duchenne and Becker muscular dystrophy due to nonsense mutations. Ann Neurol 49: 706-711, 2001. 